\title{
Cause-related Marketing: A Trade-off between Marketers and Consumers
}

\author{
Barkha Agrawal \\ Assistant Professor, IBMR, IPS Academy, Indore, Madhya Pradesh, India
}

\section{OPEN ACCESS}

Manuscript ID:

MGT-2020-08023356

\author{
Neha Sahu \\ Associate Professor, IBMR, IPS Academy, Indore, Madhya Pradesh, India \\ (D) https://orcid.org/0000-0003-1410-7530
}

Volume: 8

\begin{abstract}
The current market scenario is capricious, which makes it difficult to predict the buying intention of the customers. Even marketing practitioners are also facing difficulty in differentiating their products and services from others in an increasingly challenging business environment. This dynamism of market place generates the need for new practices. To compete with this unpredictable environment, cause-related marketing has emerged as a booming planned promotional means to satisfy the societal and ethical urge of the community. Cause-related marketing is a promotional movement of an organization wherein the charitable and communal cause is certified for brand marketing, in association with its products and services as a package. This paper is an attempt to design effective cause-related marketing strategies to compete in an uncertain environment. The analysis using statistical procedures of SPSS version 20 is done based on data of 178 consumers. Prospecting factors are identified with the help of factor analysis, which is further signified with the help of a t-test. Among those significant factors, the most prominent factor impacting buying intention is identified through hierarchical regression. The findings of this study will provide a strong base to the marketers in making decisions while designing their cause-related marketing stratagems to make cause-related marketing campaigns more operative and successful. The study concludes that management should concentrate on social cause while being concerned with the company's bottom line. The author also put forward the research directions intended to facilitate scholars to further progress the assimilation of premeditated promotion and causerelated marketing.
\end{abstract}

Keywords: Cause-Related Marketing, Buying Intention, Cause Importance, Proximity, Brand Cause Association and Corporate Motive

Citation:

Agrawal, Barkha, and Neha

Sahu. "Cause-Related

Marketing: A Trade-off

between Marketers and

Consumers." Shanlax

International Journal of

Management, vol. 8, no. 2, 2020, pp. 7-12.

\section{DOI:}

https://doi.org/10.34293/

management.v8i2.3356

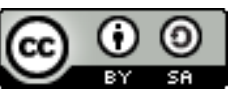

This work is licensed under a Creative Commons Attribution-ShareAlike 4.0 International License.

\section{Introduction}

In the current ever-changing business market, companies are striving hard to survive in the global competitive environment. To create a sustainable competitive advantage through greater brand awareness and constructive corporate reputation in this hyper-dynamic environment, cause-related marketing has emerged as an operative marketing tool. During the last few years, cause-related marketing has experienced unparalleled growth in the marketing model as a viable business set-up and a source of lasting competitive advantage (Porter and Kramer, 2002; Larson et al., 2008). As stated by Marconi (2002), cause-related marketing is "the action through which a company and a non-profit organization, or a similar entity market an image, a product, a service or a message for mutual benefit."

The initiation of cause-related marketing took place over three decades. Cause-related marketing has grown and progressed into a recognized practice. It has emerged as a new path for businesses and non-profits to attain remarkable outcomes and societal influence. From its initial commencement, cause-related marketing is evident and has grown in range, numbers, and depth. 
From the day the first cause-related marketing campaign was launched, the face of support to the corporate community has changed. Corporations are working ahead of traditional philanthropic charity. Being public about a particular cause upheld by the company provides the exclusive personality of the company, reveals their purpose, and assists them in a tie with suppliers, investors, employees, customers, and the community.

At times the benefits of cause-related promoting are commercial, planning to upgrade deals and showcase share, whereas at other minute centers is more on situating and notoriety building of a brand, item, or company. In both conditions, the objective is very clear. Companies are looking forward to deliberately line up their back to a cause with crucial corporate destinations.

To ascertain long-term differentiation of company from competitors along with attaching value to the corporate image, cause-related marketing is assumed as an instrument. Smith (1994) states that corporate citizens develop a broader vision and choose ways to align their self-interest with the welfare of society. Strategies are looked upon to integrate the profitmaking objective of the company with the good of humanity at large so that the entire company can be guided on a socially responsible path.

\section{Literature Review}

This section enhances the understanding of how marketers connect the buying requirements of customers through cause-related marketing. The assessment of researches available on the prospects of cause-related marketing linked to the study is mentioned. One of the researchers exposed the inclination of Utopian consumers to assist the societal and environmental programs of companies. $\mathrm{He}$ concluded that consumer's willingness to support CSR \& CRM activities of food companies is affected a lot by trust and loyalty. The study also focuses on the preference of consumers for CSR \& CRM. Specifically, it gives insight into the most selected initiatives by consumers. (Lerro). Another study gives the impression that a positive reaction of customer self-construal is connected through sympathy on buyers' reactions to corporate CRM. (Hsin-Ti Yang).
On the same track, another author also exposed that the consumer's attitude is affected by the CSR and CRM concepts. It also proposed that CRM can be extra cost competent, but the positive effect of CRM is limited to the high affinity of customers with the cause. (Beise-Zee). Demetriou recognized, the shopper depth of understanding for the company's inclusion in CRM, also examined the significance and worth of CRM in progressing the firm's corporate picture. The investigation pointed out that the organizations are accepted to be enthusiastically involved in CSR exercises through cause-related promotion by most of the buyers. (Demetriou). Another author considering the concept of congruity or "fit" in the cause-related marketing (CRM), the researcher evaluated the charity campaigns based on the pairing between for-profit and non-profit organizations, which equally affects their buying intention. The study also focused on the role played by this concept in shaping perception of consumers for the "relatedness" of products and causes. (Barkha Agrawal). Another study concentrating on global and local companies/brands focused on the success of cause related to global and local water protection. The research targets global consumer citizenship, which operates as a mediator of consumers' attitudes and their readiness to pay for cause-related marketing. According to this research, across countries, the attitude towards cause-related marketing is positive. Global citizens, mainly related to global companies, are more positive and more likely to pay for global cause before local cause. (Strizhakova)

\section{Objectives}

- To identify the prospecting factors that influence the buying intention of consumers.

- To examine the significance of the aboveidentified factors.

- To identify the most prominent factor impacting the buying intention of consumers.

\section{Methodology and Data Analysis}

For meeting the objectives of the current research, primary data is collected through a questionnaire. A 7 point Likert scale was developed, comprising of 34 items that were generated from the literature. Non-Probabilistic convenience sampling technique 
was used to establish the elements of the sample. A response rate of 81.8 percent was achieved with 180 valid responses out of 220 respondents. To determine different dimensions of cause-related marketing, inferential statistics have been conducted to analyze the data. The collected data is analyzed in three stages. Appropriate statistical tools are used to attain the objectives of the study in various belowmentioned stages:

Figure 1: Stages of Data Analysis

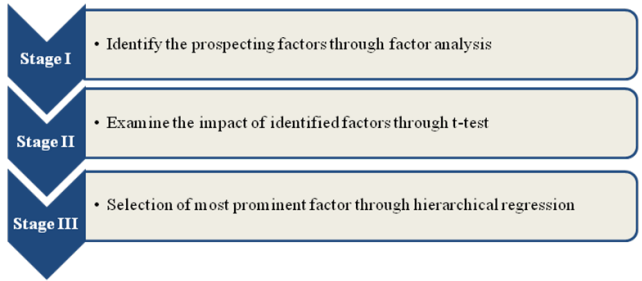

\section{Results and Discussion}

\section{Stage I: Identify the Prospecting Factors through Factor Analysis}

Among the 34 items, there are 6 factors extracted, namely Brand cause association, Extent of Elaboration, Familiarity, Cause Importance, Cause Proximity, and Corporate Motive, which influences the buying intention of consumers for cause-related products. The value of KMO statistics is .946. Thus we can deduce that the sampling is adequate, and the results are valid. The factor loading extracted from factor analysis is mentioned in figure 2 . The highest factor load is of brand cause association (11.748), which is followed by the extent of elaboration (7.039), familiarity (3.223), cause importance (3.002), cause proximity (2.195), and corporate motive (2.130), respectively. The above-mentioned factors are considered for further analysis.

Figure 2: Factors Influencing Buying Intention

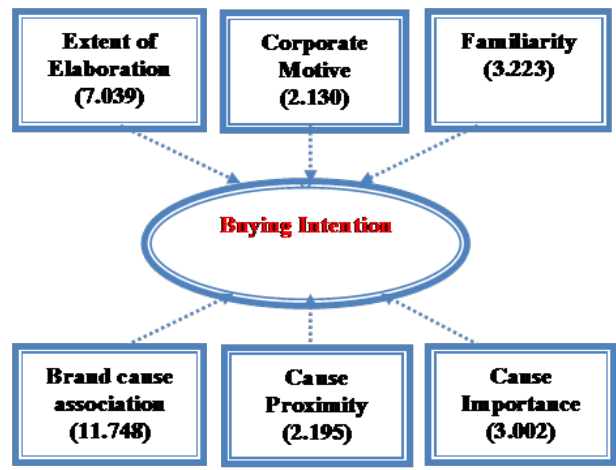

Stage II: Examine the Impact of Identified Factors through t-Test

To measure the impact of individual factors on the buying intention of customers, certain hypotheses are framed:

$\mathbf{H}_{01}$ : There is no significant impact of Brand cause association on buying intention.

$\mathbf{H}_{\mathbf{0} 2}$ : There is no significant impact of Extent of Elaboration on buying intention.

$\mathbf{H}_{\mathbf{0}}$ : There is no significant impact of Familiarity on buying intention.

$\mathbf{H}_{04}$ : There is no significant impact of Cause Importance on buying intention.

$\mathbf{H}_{\mathbf{0 5}}$ : There is no significant impact of Cause Proximity on buying intention.

$\mathbf{H}_{\mathbf{0 6}}$ : There is no significant impact of Corporate motive on buying intention.

Table 1: Result of t-test

\begin{tabular}{|c|c|c|c|c|c|}
\hline Factors & $\begin{array}{c}\mathbf{t} \\
\text { value }\end{array}$ & Df & $\begin{array}{c}\text { Mean } \\
\text { Difference }\end{array}$ & $\begin{array}{c}\mathbf{p} \\
\text { value }\end{array}$ & Remark \\
\hline BCA & 9.027 & 178 & 2.220 & .000 & Sig. \\
\hline EOE & 6.698 & 178 & 1.529 & .000 & Sig. \\
\hline F & 6.083 & 178 & 1.689 & .000 & Sig. \\
\hline CI & 5.540 & 178 & 1.356 & .000 & Sig. \\
\hline CP & -1.490 & 178 & -.257 & .138 & Insig. \\
\hline CM & 5.672 & 178 & 1.511 & .000 & Sig. \\
\hline
\end{tabular}

Source: Primary Data

The above table shows that all the hypotheses are significantly accepted as per the independent sample t-test at 5\% significance level as the calculated value (.000) except cause proximity with significance value (0.138), which implies that the distance between the consumer and the location of donation action, does not accordingly affect the buying intention.

\section{Stage III: Selection of most Prominent Factor through Hierarchical Regression}

A six-stage hierarchical multiple regression was conducted with buying intention as the dependent variable. The chronological order of variables as per factor loading was adopted for stepwise hierarchical regression. Brand Cause association was entered at stage one of the regression, extent of elaboration was entered at stage two, familiarity at stage three, cause importance at stage four, cause proximity at stage five, $\&$ corporate motive at stage six. The stepwise hierarchical regression is represented in table 2. 
International Journal of Management

\section{Table 2: Summary of Stepwise Hierarchical Regression}

\begin{tabular}{|c|c|c|c|c|c|c|c|}
\hline & Variable & $\bar{\beta}$ & t & S.E & $\mathbf{R}$ & $\overline{\mathbf{R}^{2}}$ & $\triangle \mathbf{R}^{2}$ \\
\hline \multirow[t]{2}{*}{ Step 1} & & & & & .708 & .502 & .502 \\
\hline & Brand Cause Association & .722 & 13.393 & .054 & & & \\
\hline \multirow[t]{3}{*}{ Step 2} & & & & & .763 & .582 & .080 \\
\hline & Brand Cause Association & .391 & 5.180 & .076 & & & \\
\hline & Extent of Elaboration & .413 & 5.802 & .071 & & & \\
\hline \multirow[t]{4}{*}{ Step 3} & & & & & .763 & .582 & .001 \\
\hline & Brand Cause Association & .369 & 4.387 & .084 & & & \\
\hline & Extent of Elaboration & .402 & 5.449 & .074 & & & \\
\hline & Familiarity & .043 & .623 & .070 & & & \\
\hline \multirow[t]{5}{*}{ Step 4} & & & & & .764 & .583 & .001 \\
\hline & Brand Cause Association & .407 & 3.710 & .110 & & & \\
\hline & Extent of Elaboration & .403 & 5.455 & .074 & & & \\
\hline & Familiarity & .042 & .599 & .070 & & & \\
\hline & Cause Importance & -.045 & -.551 & .081 & & & \\
\hline \multirow[t]{6}{*}{ Step 5} & & & & & .784 & .615 & .032 \\
\hline & Brand Cause Association & .385 & 3.636 & .106 & & & \\
\hline & Extent of Elaboration & .414 & 5.800 & .071 & & & \\
\hline & Familiarity & .053 & .791 & .067 & & & \\
\hline & Cause Importance & -.008 & -.107 & .079 & & & \\
\hline & Cause Proximity & -.146 & -3.815 & .038 & & & \\
\hline \multirow[t]{7}{*}{ Step 6} & & & & & .788 & .622 & .006 \\
\hline & Brand Cause Association & .361 & 3.393 & .106 & & & \\
\hline & Extent of Elaboration & .396 & 5.532 & .072 & & & \\
\hline & Familiarity & .004 & .053 & .073 & & & \\
\hline & Cause Importance & -.003 & -.032 & .078 & & & \\
\hline & Cause Proximity & -.148 & -3.879 & .038 & & & \\
\hline & Cause Motive & .108 & 1.706 & .063 & & & \\
\hline
\end{tabular}

Source: Primary Data

The stepwise progressive relapse uncovered that at arranging BCA contributed altogether to the relapse show $(\mathrm{F}=179.386, \mathrm{p}<.05)$ and accounted for $50.2 \%$ of the variety in buying purposeful. Presenting the degree of elaboration variable clarified an extra $8.0 \%$ of variety in buying purposeful, and this alter in $\mathrm{R}^{2}$ was critical $(\mathrm{F}=33.659, \mathrm{p}<.05)$. Including recognition of the relapse, the show clarified an extra $0.1 \%$ of the variety in buying deliberate, and this alter in $\mathrm{R}^{2}$ was noteworthy $(\mathrm{F}=$ $.389, \mathrm{p}<.05)$. The expansion of cause significance variable to the relapse show clarified an extra $0.1 \%$ of the variety in buying deliberate, and this alter in $\mathrm{R}^{2}$ was critical $(\mathrm{F}=.304, \mathrm{p}<.05)$. Including cause nearness to the relapse, show clarified an extra 3.2\% of the variety in buying purposeful, and this alter in $\mathrm{R}^{2}$ was noteworthy $(\mathrm{F}=14.557, \mathrm{p}<.05)$. At long last, the expansion of cause thought process variable to the relapse demonstrate clarified an extra $0.6 \%$ of the variety in buying purposeful, and this alter in $\mathrm{R}^{2}$ was critical $(\mathrm{F}=2.909, \mathrm{p}<.05)$. When all the six autonomous factors are included within step six of the relapse show, not one or the other cause significance, recognition, nor because the rationale is critical predictors of buying purposeful. The foremost imperative indicator of buying deliberate is brand cause affiliation, which extraordinarily clarified $50.2 \%$ of the variety in buying deliberately. 
Together the six free factors accounted for $62.2 \%$ of the fluctuation in buying purposeful.

\section{Recommendations and Concluding remarks}

A cause-related marketing program is a winwin approach that supports the business's profit goal and social cause to compete with an uncertain environment. A strong marketing strategy will create a constructive influence on consumers to accept and adopt the cause-related marketing initiatives of the companies. This work endeavors to get a glance at factors that promotes the buying intention of consumers for the products of companies involved in cause-related marketing. Brand-cause association is the prominent factor influencing the buying intention of consumers. The marketers should ensure that the cause selected by the company should fit in with the image of the brand. Low association of brands with the cause will make it difficult for the consumers to relate the two and may not help to generate a large number of sales.

Hence, it may be concluded that in today's competitive world, businesses must adopt such effective promotional strategies to attain corporate goals efficiently by serving society as well.

\section{References}

Adiwijaya, K., and R. Fauzan. "Cause-related Marketing: The Influence of Cause-Brand Fit, Firm Motives and Attribute Altruistic to Consumer Inferences and Loyalty and Moderation Effect of Consumer Values." International Proceedings on Economics Development \& Research, 2012, pp. 49-54.

Agrawal, Barkha, and C.K. Goyal. "Consumers Attitude towards Corporate social Responsibility and Cause-Related Marketing." Asian Journal of Management, vol. 9, no. 1, 2018, pp. 366-372.

Agrawal, Barkha, and Neha Sahu. "Efficacy of Cause Related Marketing: Awareness Study." UNNAYAN: International Bulletin of Management and Economics, vol. 10, 2019, pp. 348-359.

Agrawal, Barkha, and Prateek Maheshwari. "CauseRelated Marketing: A Conceptual Analysis of the Congruity Concept \& Consumer
Attitude." Unnayan: International Bulletin of Management and Economics, vol. 7, 2017, pp. 56-62.

Alcañiz, Enrique Bigné, et al. "Alliances between Brands and Social Causes: The Influence of Company Credibility on Social Responsibility Image." Journal of Business Ethics, 2010, pp. 169-186.

Anuar, Marhana, and Osman Mohamad. "Examining the Effects of Cause-Proximity and Gender on Consumers' Response to Cause-Related Marketing: Evidence from Malaysia." International Journal of Marketing Studies, vol. 3, no. 3, 2011, pp. 174-181.

Chéron, Emmanuel, et al. "The Effects of BrandCause Fit and Campaign Duration on Consumer Perception of Cause-Related Marketing in Japan." Journal of Consumer Marketing, vol. 29, no. 5, 2012, pp. 357-368.

Demetriou, Marlen, et al. "Cause-related Marketing: Building the Corporate Image While Supporting Worthwhile Causes." Journal of Brand Management, 2010, pp. 266-278.

Duarte, Paulo Alexandre de Oliveira, and Susana Costa e Silva. "The Role of Consumer-Cause Identification and Attitude in the Intention to Purchase Cause-Related Products." International Marketing Review, vol. 37, no. 4, 2018, pp. 603-620.

Irwin, Richard L., et al. "Cause-related Sport Marketing: Can this Marketing Strategy Affect Company Decision-Makers?" Journal of Management \& Organization, vol. 16, no. 4, 2010, pp. 550-556.

Lafferty, Barbara A., and Diane R. Edmondson. "Portraying the Cause Instead of the Brand in Cause-Related Marketing Ads: Does it Really Matter?" Journal of Marketing Theory and Practice, vol. 17, no. 2, 2009, pp. 129-143.

Langen, Nina, et al. "Is There Need for More Transparency and Efficiency in Cause-related Marketing?." International Journal on Food System Dynamics, vol. 1, 2010, pp. 366-381.

Lerro, Marco, et al. "Cause Related Marketing among Millennial Consumers: The Role of Trust and Loyalty in the Food Industry." Sustainability, vol. 11, 2019. 
Marconi, Joe. Cause Marketing: Build your Image and Bottom Line through Socially Responsible Partnerships, Programs, and Events, Dearborn Trade Publishing, 2002.

McDonald, Lynette M., and Sharyn Rundle-Thiele. "Corporate Social Responsibility and Bank Customer Satisfaction: A Research Agenda." International Journal of Bank Marketing, vol. 26, no. 3, 2008, pp. 170-182.

Porter, Michael E., and Mark R. Kramer. "The Competitive Advantage of Corporate Philanthropy." Harvard Business Review, 2002.

Shabbir, Rizwan, et al. "Effects of Cause-related Marketing (CRM) on Buying Decision: Does it Matter in FMCG Sector." City University Research Journal, 2017, pp. 142-152.

Shabbir, Shahbaz, et al. "Cause Related Marketing Campaigns and Consumer Purchase Intentions: The Mediating Role of Brand Awareness and Corporate Image." African Journal of Business Management, vol. 4, no. 6, 2010, pp. 1229-1235.

Sheikh, Sana-ur-Rehman, and Rian Beise-Zee. "Corporate Social Responsibility or CauseRelated Marketing? The Role of Cause Specificity of CSR." Journal of Consumer Marketing, vol. 28, no. 1, 2011, pp. 27-39.

Singh, Sangeeta, et al. "Overcoming Skepticism towards Cause Related Claims: The Case of
Norway." International Marketing Review, vol. 26, no. 3, 2009, pp. 312-326.

Strizhakova, Yuliya, et al. "Responses of Global Citizens to Cause-Related Green Marketing." Journal of International Marketing, vol. 16, no. 4, 2010, pp. 57-85.

Tangari, Andrea Heintz, et al. "The Moderating Influence of Consumers' Temporal Orientation on the Framing of Societal Needs and Corporate Responses in CauseRelated Marketing Campaigns." Journal of Advertising, vol. 39, no. 2, 2010, pp. 35-50.

Tsao, Wen-Chin, and Yu-Hua Chen. "A Study of the Impact and Application of CauseCorporate Brand Alliance on Taiwans Tourist Amusement Industry." African Journal of Business Management, vol. 5, no. 2, 2011, pp. 316-331.

Yang, Hsin-Ti, and Ghi-Feng Yen. "Consumer Responses to Corporate Cause-Related Marketing: A Serial Multiple Mediator Model of Self-Construal, Empathy and Moral Identity." European Journal of Marketing, vol. 52, no. (9/10), 2018, pp. 2105-2127.

Zdravkovic, Srdan, et al. "Dimensions of fit between a Brand and a Social Cause and their Influence on Attitudes." International Journal of Research in Marketing, vol. 27, no. 2, 2010, pp. 151-160.

\section{Author Details}

Ms. Barkha Agrawal, Assistant Professor, IBMR, IPS Academy, Indore, Madhya Pradesh, India

Email ID: barkhagrawal13@gmail.com

Dr. Neha Sahu, Associate Professor, IBMR, IPS Academy, Indore, Madhya Pradesh, India

Email ID: 08neha@gmail.com 